BENHA VETERINARY MEDICAL JOURNAL, VoL. 30, No. 1:109-117, MARCH, 2016

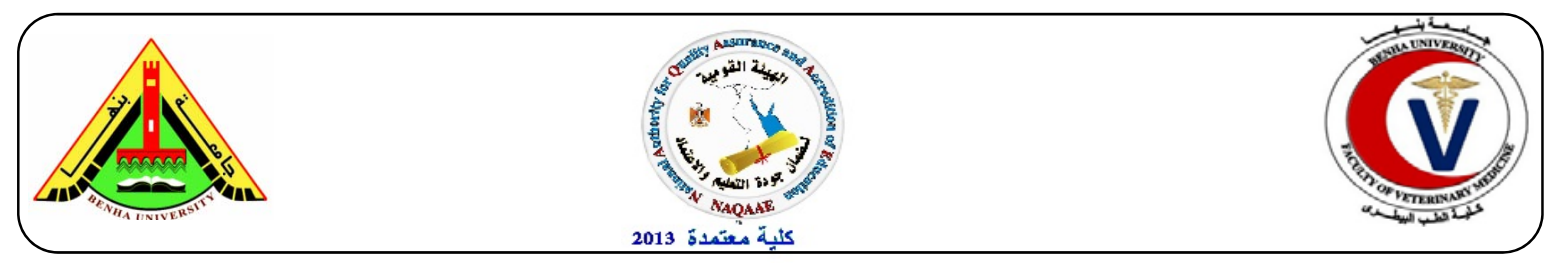

\title{
Bacterial and Chemical quality of Frozen Chicken Meat Received at Governmental Hospital modern.
}

\author{
Fatin M. Hassanien ${ }^{1}$, Rasha A. El-Sabagh ${ }^{1}$, Marionet Z. Nassief ${ }^{2}$, Mohammed S. Refat ${ }^{3}$ \\ ${ }^{1}$ Department of Meat Hygiene, Faculty of Veterinary Medicine, Benha University. ${ }^{2}$ Animal Health \\ Research Institute, Benha Branch. ${ }^{3}$ Hospital Benha University.
}

\begin{abstract}
A B S T R A C T
This study was conducted to evaluate the quality of frozen chicken meat received at governmental hospital in kalyobia governorate, Egypt. A total of 100 samples were taken from chicken breast and thigh (50 of each), randomly for bacteriological and chemical examination. The average of APC, coliform and psychrotrophes counts were $3.78 \times 10^{6} \pm 0.93 \pm 10^{6} / \mathrm{g}, \quad 2.07 \times 10^{3} \pm 0.60 \times 10^{3} / \mathrm{g}$ and $5.71 \times 10^{6} \pm 1.44 \times 10^{6} / \mathrm{g}$ for breast and $4.38 \times 10^{6} \pm 0.59 \times 10^{6} / \mathrm{g}, \quad 2.61 \times 10^{3} \pm 0.60 \times 10^{3} / \mathrm{g}$ and $4.59 \times 10^{6} \pm 1.26 \times 10^{6} / \mathrm{g}$ for thigh, respectively. Chemical keeping quality tests represented by $\mathrm{pH}, \mathrm{TVB} / \mathrm{N}$ $(\mathrm{mg} / 100 \mathrm{~g})$ and TBA $(\mathrm{mg} / \mathrm{kg})$ indicated that the mean values were $5.84 \pm 0.10,18.99 \pm 0.59$ and $0.68 \pm 0.01$ for chicken breast and $5.91 \pm 0.11,19.28 \pm 0.60$ and $0.73 \pm 0.02$ for chicken thigh, respectively. The recommended points were discussed.
\end{abstract}

Keywords: Frozen chicken meat, APC, Coliform, Psychrotrophes, pH, TVB/N and TBA. (http://www.bvmj.bu.edu.eg) (BVMJ-30(1): 109-117, 2016)

\section{INTRODUCTION}

$P_{\text {an }}$ hicken consumption has considerably increased with an annual growth rate of $6 \%$. (Davies and Board, 1998) and the global production of broiler meat increased from 73.1 million tons in 2008 to 83.1 million tons in 2012 (USDA, 2012), since it represents a major component of the human diet and chicken is an important low cost source of animal protein (Cohen et al., 2007). It offers several advantages over red meat that account for an increasing trend in chicken consumption; cuts are easier to handle, the meat is associated with fewer religious restrictions and has relatively low fat and cholesterol contents; it is recognized as a healthier food option (Jaturasitha et al., 2008 and Liu et al., 2012). Freezing is considered an excellent method for keeping quality of chicken meat for long period (9-12month) at temperature below $-18^{\circ} \mathrm{C}$, as during the freezing, growth of many types of microorganisms will be ceased due to metabolic injury while others especially psychrotrophic bacteria can grow until the medium freezes (Davies and Board, 1998). Psychrotrophic bacteria are responsible for many undesirable changes in flavor, odor, texture and color of the food products. Deterioration of chicken meat caused by chemical and/or physical factors can occur depending on the microbiological conditions of poultry carcasses which are directly affected by slaughter, sanitization and storage conditions (Balamatsia et al., 2006). Poultry meat quality based mainly on the determination of microbial and chemical attributes (Byun et al., 2003). The Aerobic Plate Count is considered as an index of quality, which gives an idea about the hygienic measures during processing and help in assessing the keeping quality (Aberle et al., 2001). Also, the coliform group of bacteria is a reliable indicator of fecal pollution, improper handling and storage of meat and meat products. 
The $\mathrm{pH}$ value is an indicator of the keeping quality of chicken meat where the $\mathrm{pH}$ measurement is used to assess the shelf life and quality of the products as $\mathrm{pH}$ values plays an important role for the microbiological growth affecting the shelf life of the products (Hathout-Amal and Aly -Soher, 2010). Moreover, the variation of $\mathrm{TVB} / \mathrm{N}$ values of examined samples of chicken meat could be attributed to the variation of protein content and storage life of each chicken meat product. Also, it is more useful for assessing the degree of meat deterioration than for evaluating the changes occur during the first stages of storage (El Marrakchi et al., 1990). The variation of TBA values of examined samples of chicken meat could be attributed to the variation of fat content and storage life of each product and so TBA is good indicator of quality of chicken meat through the assessment of the degree of lipid oxidation (Raharjo and Sofos, 1993).

Therefore, the aim of the present study was to throw a light on the bacteriological and chemical criteria of frozen chicken meat received at governmental hospital and its suitability for human consumption.

\section{MATERIAL AND METHODS}

\subsection{Collection of samples}

A grand total of 100 random samples of frozen chicken meat classified into breast and thigh (50 of each) were collected from Governmental hospital at Kalyobia Governorate. The collected samples were transferred directly to the laboratory in an ice box under complete aseptic conditions without undue delay and then subjected to following examination after thawing in the refrigerator overnight.

\subsection{Preparation of samples (ISO, 2003)}

Twenty-five grams of the examined chicken recommended cuts samples were transferred to a septic blender jar and 225 $\mathrm{ml}$ of $0.1 \%$ sterile peptone water were aseptically added to the content of jar. Each sample was then homogenized in the stomacher at 2000 r.p.m for 1-2 minutes to provide a homogenate, from which tenth fold serial dilutions were prepared (by adding $1 \mathrm{ml}$ from food homogenate to $9 \mathrm{ml}$ of $0.1 \%$ sterile peptone water tube then take $1 \mathrm{ml}$ from this tube to another one containing $9 \mathrm{ml}$ of sterile peptone water and so on).

\subsection{Examination of samples}

The prepared samples were subjected to the following examination:

- Determination of Aerobic plate count (APHA, 2001).

- Determination of Total coliform count (ISO, 2004).

- Determination of total Psychrotrophic count (APHA, 2001).

- Determination of $\mathrm{pH}$ value (E.O.S 63/11, 2006).

- Determination of Thiobarbituric Acid (TBA) “mg/Kg” (E.O.S 63/9, 2006).

- Determination of Total Volatile Basic Nitrogen (TVB/N) "mg\%" (E.O.S 63/10, 2006).

\section{RESULTS}

\subsection{Aerobic Plate Count}

It is evident from the results recorded in table (1) that the APC in the examined samples was varied from $2.40 \times 10^{6}$ to $5.5 \times 10^{6}$ with an average value of $3.78 \times 10^{6} \pm 0.93 \times 10^{6}$ for breast and $3.30 \times 10^{6}$ to $6.30 \times 10^{6}$ with an average value of $4.38 \times 10^{6} \pm 0.59 \times 10^{6} \mathrm{cfu} / \mathrm{g}$ for thigh. In other words, there is a highly significant difference of APC between the examined chicken meat breast and thigh $(\mathrm{P}<0.05)$.

\subsection{Total Coliform Count}

Results recorded in table (2) declared that the total coliform count/g in the examined chicken meat samples were varied from $1.30 \times 10^{3}$ to $3.10 \times 10^{3}$ with a mean value of $2.07 \times 10^{3} \pm 0.60 \times 10^{3}$ for breast and from $1.80 \times 10^{3}$ to $5.0 \times 10^{3}$ with a mean of $2.61 \times 10^{3} \pm 0.60 \times 10^{3}$ for thigh. There is a significant difference $(\mathrm{P}<0.05>)$ between 
the examined chicken meat samples (breast and thigh).

\subsection{Total Psychrotrophic count}

Table (3) declared that the total psychrotrophic count in the examined samples of chicken meat was ranged from $2.20 \times 10^{6}$ to $6.30 \times 10^{6}$ with a mean value of $5.71 \times 10^{6} \pm 1.44 \times 10^{6} \mathrm{cfu} / \mathrm{g}$ for breast and from $3.90 \times 10^{6}$ to $7.80 \times 10^{6}$ with a mean value of $4.59 \times 10^{6} \pm 1.26 \times 10^{6} \mathrm{cfu} / \mathrm{g}$ for thigh. There is a significant difference $(\mathrm{P}<0.05)$ between the examined chicken meats samples (breast and thigh).

\section{4. $p H$}

Table (4) indicated that the $\mathrm{pH}$ value of the examined chicken meat varied from 4.47 to 7.12 with a mean $5.84 \pm 0.10$ for breast and from 4.52 to 7.2 with a mean of $5.91 \pm 0.11$ for thigh. There is a significant difference $(\mathrm{P}<0.05>)$ between the examined chicken meats samples (breast and thigh).

\subsection{Total Volatile Basic Nitrogen}

Table (5) indicated that the TVN value varied from 11.10 to 31.00 with a mean $18.99 \pm 0.59$ for examined breast and from 11.50 to 32.00 with a mean $19.28 \pm 0.60$ for examined thigh samples. There is a significant difference $(\mathrm{P}<0.05>)$ between the examined chicken meat samples (breast and thigh).

\subsection{Thiobarbituric Acid}

Results achieved in table (6)revealed that the TBA value of the examined chicken meat varied from $0.47-0.99$ with a mean $0.68 \pm 0.01$ for breast and from 0.51 to 1.20 with a mean of $0.73 \pm 0.02$ for thigh. There is a significant difference $(\mathrm{P}<0.05>)$ between the examined chicken meats samples (breast and thigh).

Table (1): Statistical analytical results of Aerobic plate counts/g (APC) and Acceptability of examined samples of frozen chicken breast and thigh $(\mathrm{n}=50)$.

\begin{tabular}{lcccccc}
\hline chicken & Min. & Max. & Mean \pm S.E & \multicolumn{2}{c}{$\begin{array}{c}\text { Egyptian } \\
\text { standard }\end{array}$} & \multicolumn{2}{c}{$\begin{array}{c}\text { Non accepted } \\
\text { samples }\end{array}$} \\
meat & & & & MPL* & No & $\%$ \\
\hline Breast & $2.40 \times 10^{6}$ & $5.5 \times 10^{6}$ & $3.78 \times 10^{6} \pm 0.93 \times 10^{6++}$ & $10^{5}$ & 50 & 100 \\
Thigh & $3.30 \times 10^{6}$ & $6.30 \times 10^{6}$ & $4.38 \times 10^{6} \pm 0.59 \times 10^{6}$ & $10^{5}$ & 50 & 100 \\
\hline
\end{tabular}

S.E $E^{*}=$ Standard error of mean, $++=$ High significant differences $(P<0.05)$ by T-test. $*$ MPL $=$ Maximum permissible limit according to Egyptian Organization for standardization (ES, 1090/ 2005).

Table (2): Statistical analytical results of Total Coliform Count / g and Acceptability of examined samples of frozen chicken breast and thigh $(\mathrm{n}=50)$.

\begin{tabular}{|c|c|c|c|c|c|c|}
\hline \multirow{2}{*}{$\begin{array}{l}\text { Chicken } \\
\text { meat }\end{array}$} & \multirow[t]{2}{*}{ Min. } & \multirow[t]{2}{*}{ Max. } & \multirow[t]{2}{*}{ Mean \pm S.E ${ }^{*}$} & \multirow{2}{*}{$\begin{array}{l}\text { Egyptian } \\
\text { standard } \\
\text { MPL* }\end{array}$} & \multicolumn{2}{|c|}{$\begin{array}{c}\text { Non accepted } \\
\text { samples }\end{array}$} \\
\hline & & & & & No & $\%$ \\
\hline Breast & $1.30 \times 10^{3}$ & $3.10 \times 10^{3}$ & $2.07 \times 10^{3} \pm 0.60 \times 10^{3+}$ & & 50 & 100 \\
\hline Thigh & $1.80 \times 10^{3}$ & $5.0 \times 10^{3}$ & $2.61 \times 10^{3} \pm 0.60 \times 10^{3}$ & Free & 50 & 100 \\
\hline
\end{tabular}


Table (3): Statistical analytical results of Total Pscychrotrophic Count /g and Acceptability of examined samples of frozen chicken breast and thigh $(n=50)$.

\begin{tabular}{lcccccc}
\hline $\begin{array}{l}\text { Chicken } \\
\text { meat }\end{array}$ & Min. & Max. & Mean \pm S.E $^{*}$ & $\begin{array}{c}\text { Egyptian } \\
\text { standard } \\
\text { MPL* }\end{array}$ & \multicolumn{2}{c}{$\begin{array}{c}\text { Non accepted } \\
\text { samples }\end{array}$} \\
\hline Breast & $2.20 \times 10^{6}$ & $6.30 \times 10^{6}$ & $5.71 \times 10^{6} \pm 1.44 \times 10^{6+}$ & $10^{5}$ & 50 & $\%$ \\
Thigh & $3.90 \times 10^{6}$ & $7.80 \times 10^{6}$ & $4.59 \times 10^{6} \pm 1.26 \times 10^{6}$ & & 50 & 100 \\
\hline
\end{tabular}

Table (4): Statistical analytical results of $\mathrm{pH}$ and Acceptability of examined samples of frozen chicken breast and thigh $(\mathrm{n}=50)$.

\begin{tabular}{lcccccc}
\hline Chicken meat & Min. & Max. & Mean \pm S.E & $\begin{array}{c}\text { Egyptian } \\
\text { standard } \\
\text { MPL* }\end{array}$ & Non accepted samples \\
NO & \\
\hline Breast & 4.47 & 7.12 & $5.84 \pm 0.10^{+}$ & & 17 & 34 \\
Thigh & 4.52 & 7.20 & $5.91 \pm 0.11$ & $5.5-6.5$ & 17 & 34 \\
\hline
\end{tabular}

Table (5): Statistical analytical results of TVB/N and Acceptability of examined samples of frozen chicken breast and thigh $(\mathrm{n}=50)$.

\begin{tabular}{lcccccc}
\hline $\begin{array}{l}\text { Chicken } \\
\text { meat }\end{array}$ & Min. & Max. & Mean \pm S.E $^{*}$ & $\begin{array}{c}\text { Egyptian } \\
\text { standard } \\
\text { MPL* }\end{array}$ & NO & $\%$ \\
\hline Breast & 11.10 & 31.00 & $18.99 \pm 0.59^{+}$ & $20 \mathrm{mg} / 100 \mathrm{~g}$ & 19 & 38 \\
Thigh & 11.50 & 32.00 & $19.28 \pm 0.60$ & & 19 & 38 \\
\hline
\end{tabular}

Table (6): Statistical analytical results of TBA and Acceptability of examined samples of frozen chicken breast and thigh $(\mathrm{n}=50)$.

\begin{tabular}{lcccccc}
\hline Chicken meat & Min. & Max. & Mean \pm S.E & $\begin{array}{c}\text { Egyptian } \\
\text { standard } \\
\text { MPL* }\end{array}$ & No & $\%$ \\
\hline Breast & 0.47 & 0.99 & $0.68 \pm 0.01^{+}$ & $0.9 \mathrm{mg} / \mathrm{kg}$ & 7 & 14 \\
Thigh & 0.51 & 1.20 & $0.73 \pm 0.02$ & & 7 \\
\hline
\end{tabular}

\section{DISCUSSION}

It is evident from the result recorded in table (1) that the Total APC in examined samples nearly similar to that obtained by Saikia and Joshi (2010) who mentioned that the mean value of aerobic plate count in chicken meat was $3.7 \times 10^{6} \mathrm{cfu} / \mathrm{g}$. for breast and $2.4 \times 10^{6}$ $\mathrm{cfu} / \mathrm{g}$. for thigh. Lower results were obtained by Daoud et al. (2012) who found that the mean value of APC was $2.1 \times 10^{3}$ $\mathrm{cfu} / \mathrm{g}$ for breast and $2.7 \times 10^{3} \mathrm{cfu} / \mathrm{g}$ for thigh. Higher APC in chicken meat obtained by
Hassan-Ola (2015) who found that the mean value of $\mathrm{APC}$ was $4 \times 10^{7} \pm 5 \times 10^{6}$ in examined 50 chicken breast meat. As shown in table (1), $100 \%$ of the examined samples exceeded limits according to the safe permissible limits stipulated by EOS (1090/2005) for APC (not exceed $10^{5} \mathrm{cfu} / \mathrm{g}$ $\left.=5 \log _{10} \mathrm{cfu} / \mathrm{g}\right)$. Although, the APC of any food articles are not sure indicative of their safety for consumption, yet it is of supreme importance in judging the hygienic condition under which food has been produced, handled and stored. The three main routs by which microorganisms enter 
the food are food itself, food handlers and environment, and raw food is never sterile (Roberts, 1990). The higher APC in chicken meat was due to the cross contamination of the carcasses during slaughtering process. Moreover, the carcasses are kept at ambient temperature, which allow the multiplication of mesophilic micro-organisms. Moreover, the chopping tables which manufactured from wood were considered as a source of contamination when they used every day without proper cleanliness. This enhanced the chance of cross contamination for uninfected carcass. The total coliform count in examined samples was nearly similar to that obtained by Hassan- Ola (2015) who mentioned that the mean value of TCCin chicken meat was $1.7 \times 10^{3} \mathrm{cfu} / \mathrm{g}$. Lower results were obtained by Daoud et al., (2012) whofound that the mean value of total coliform count was $5.1 \times 10 \mathrm{cfu} / \mathrm{g}$ (table 2) and Higher total coliform count in chicken meat was obtained by Javadi and Safaramashae (2011) whofound that the mean value was $1.4 \times 10^{4}$ in examined chicken meat. Comparing to the maximum permissible limits stipulated by EOS (1090/2005), for coliforms count (free from coliforms), it is clear that $100 \%$ of the examined chicken breast and thigh samples were unaccepted. Detection of coliform is used as indicator of water pollution or as a general indicator of sanitary condition in in the food processing environment (Feng et al., 2002). Also, high Coliform count indicated poor hygienic quality of meat. And was significant as indicator of fecal contamination, also had the ability to grow well over wide range of temperature below $10^{\circ} \mathrm{C}$ up to $46{ }^{\circ} \mathrm{C}$ (Gill et al., 1996). The contamination with Coliforms may occur during slaughtering, cutting or dressing of carcasses, soiled hands, shopping blocks or knives for handling and cutting, also contaminated water considered as a source of Coliforms in meat (Yadav et al., 2006). However, its presence in great numbers may be responsible for inferior quality of meat products resulting in economic losses and the possibility of presence of enteric pathogens which constitute public health hazard (Trout and Osburn, 1997).

It is evident from the result recorded in table (3) that the total psychrotrophes count in examined chicken meat samples nearly similar to that obtained by Belal (1997) who mentioned that the mean value was $6.2 \pm 5.68(\log 10) \mathrm{cfu} / \mathrm{g}$. In contrast, lower results were obtained by Dan et al. (2008) who found that the mean value was $2.88 \pm 0.32(\log 10) \mathrm{cfu} / \mathrm{g}$. In other words, $100 \%$ of the examined samples exceeded limits according to the safe permissible limits stipulated by EOS (1090/2005) for Total Psychrotrophes count (not exceed $10^{5}$ $\mathrm{cfu} / \mathrm{g}=5 \log _{10} \mathrm{cfu} / \mathrm{g}$ ) (Table 3). In general, the contamination of chicken meat with great number of psychrotrophes could be attributed to the neglected sanitary measures adapted during intensive preparation, processing, handling and packaging as well as cold storage. (Cenci et al.1990). Furthermore, the contaminated equipment and knives are probably the principle contributing factors to high psychrotrophic count of such chicken meat product (Davies and Board, 1998). During freezing of chicken meat, the growth of many types' microorganisms will cease while others especially psychrotrophic bacteria can grow until the medium freezes, (Davies and Board, 1998). Accordingly, psychrotrophes appear to be less susceptible to cold chock and become the major organisms responsible for spoilage of such food item (Potter, 2001). Psychrotrophic bacteria are responsible for many undesirable changes bin flavor, odor, texture and color of food products especially among that stored for extended periods under various installed refrigeration devices (Fraizer and Westhoff, 1984). The $\mathrm{pH}$ value is an indicator for the keeping quality of meat where the $\mathrm{pH}$ measurement is used to assess the shelf life and quality of the products. As shown in table (4), the obtained results of $\mathrm{pH}$ were similar to those obtained by Fathy-Eman (2012), $5.91 \pm 0.01$ to $6.03 \pm 0.18$ for breast and $5.77 \pm 0.01$ for thigh, but higher results were 
achieved by Afifi-Jehan (2000), 6.15 for breast and 6.21 for breast.

Comparing to the safe permissible limits of pH stipulated by EOS (1090/2005) (5.5$6.5), 34 \%$ of the examined breast and thigh samples were not within the accepted level, as shown in table (4). The decrease in $\mathrm{pH}$ value in chicken meat may be attributed to the breakdown of glycogen with the formation of lactic acid and the increase of $\mathrm{pH}$ may be due to the partial proteolysis leading to the increase of free alkaline groups depending on the condition of such changes. Besides, higher $\mathrm{PH}$ values of breast muscle could be due to the increase in the lactic acid concentration via anaerobic metabolism (Jay, 1972). In general, $\mathrm{pH}$ plays an important role in controlling the growth of microorganisms, for example, the growth of Enterobacteriacae and psychrotrophesis retarded or prevented under $\mathrm{pH}$ 5.4-5.8 (Kunz, 1994). It is evident from the results recorded in table (5) that obtained results of $\mathrm{TVB} / \mathrm{N}$ were higher than obtained by Hassan-Fatma Elzhraa (2013) (9.11 \pm 0.33 for breast) and Abdel-Zahir-Hager (2013) $(9.11 \pm 0.22$ for thigh). But higher results was obtained by Hassanin-Fatin and Hassan, M.A (2003) (30.76 \pm 1.07$)$. Comparing to the safe permissible limits stipulated by EOS (1090/2005), (TVB/N lower than $20 \mathrm{mg} / 100 \mathrm{gm}), 38 \%$ of the examined samples were higher than the safe standard limit. $\mathrm{TVB} / \mathrm{N}$ in poultry meat may be increased as the days of storage increased (Reddy et al.,1970), the increase in TVB/N value in meat during storage might be attributed to the breakdown of protein as a result of activity of microbial strains and proteolytic enzymes (Yassien-Nessrien, 2003) and (Alina and Ovidiu, 2007). The increase to critical values indicates inciepient spoilage of chicken meat product samples after different periods of storage (Hassanin-Fatin and Hassan, 2003). As shown in table (6), the obtained results of TBA were similar to those obtained by (Santosh kumar et al., 2014) (0.42 \pm 0.19 to $0.8 \pm 0.3)$ and lower results were obtained by
(Fathy-Eman, 2012) $(0.04 \pm 0.01$ for breast and $0.09 \pm 0.01$ for thigh). Higher results were obtained by (Shams El-Din and Ibrahim, 1990) (0.58-1.69 for breast). Comparing to the safe permissible limits stipulated by EOS (1090/2005), (TBA lower than $0.9 \mathrm{mg} / \mathrm{kg}), 14 \%$ of the examined chicken meat samples were higher than the safe standard value. The quality of meat and chicken meat products during the chilling or freezing depends greatly on TBA value as recommended by (Hassan and Shaltout, 2004). The variation of TBA values of examined chicken meat samples could be attributed to the variation of fat content of different samples under examination and storage life and Development of off-flavors known as rancidity is due to lipid oxidation (Owens, 2001), and so the Thiobarbituric acid value is routinely used as index of lipid oxidation in stored meat products (SalemAmany, 1992, Raharjo and Sofos, 1993 and Abd El-Kader, 1996).

\section{CONCLUSION}

From the result achieved in the present study, one may conclude that examined frozen chicken samples collected from governmental hospital in Kalyobia governorate had unsatisfactory condition which may be attributed to various factors among which transportation, handling, distribution and storage. There is no doubt that the contamination of examined chicken meat with different types of coliform, staphylococci, E. coli and psychrotrophes constitute a public health hazard besides being responsible for undesirable changes in these chickens which render them unfit for human consumption. All poultry establishments develop and implement a system of preventive control designed to reduce the bacterial load of poultry intended for freezing to a great extent and so improve the safety of their products, known as HACCP (Hazard Analysis and Critical Control Points).

\section{REFERENCES}


Abd El-Kader, Z. M. 1996. Lipid oxidation in chicken as affected by cooking and frozen storage. Nahrung, 40(1): 2142.

Abdel-Zahir-Hager 2013. Chemical aspect of chicken cut-up meat products, M.V.Sc. Thesis, Fac. Vet. Med. Moshtohor, Benha Univ. Egypt.

Aberle, E.D., Forrest, J., Gerrard, D.E., Mills, E.W. 2001. Principles of meat science ( $4^{\text {th }}$ edition). Hunt Puplishing Co., Kendall, USA.

Afifi-Jehan, S.A. 2000. Chemical studies on some poultry meat products M.V.Sci. Thesis, Fac. Vet. Med. Zagazig Univ.Egypt.

Alina, H., Ovidiu, T. 2007. Determination of total protein in some meat products. Analele Stiintifice ale Universitatii, Alexandru loan Cuza Sectiunea Genetica si Biologie Moleculara, TOM VIII.

American Public Health Association "APHA". 2001. Compendium of methods for microbiological examination of foods, $4^{\text {th }}$ Edition 365 366. 800. $1^{\text {st }}, \mathrm{NW}$ Washington DC 2000. 1-3710. USA

Balamatsia, C. C., Paleologos, E.K., Kontominas, M.G., Savvaidis, I.N. 2006. Correlation between microbial flora, sensory changes and biogenic amines formation in fresh chicken meat stored aerobically or under modified atmosphere packaging at $4 \mathrm{C}$ : possible role of biogenic amines as spoilage indicators, Antonie van Leeuwenhoek, Springerlink, 89: 9-17.

Belal, H. 1997. Microbiological studies of poultry cut-up products. M.V.Sc. Thesis Meat Hygiene, Fac. Vet. Med., Moshtohor, Zagazig Univ., (Benha Branch).

Byun, J.S., Min, J.S., Kim, J.W., Chung, M.S., Lee, M. 2003. Comparison of indicators of microbial quality of meat during aerobic cold storage. J. Food Protect.66:1733-1737.

Cenci, P., Corrodini, L., Vitaioli, M., Rausa, G.1990. Comparison of the microbiological profile of rural and industrial poultry 1. Enterobacteriacae. Igiene moderna, 94(2):207-211.

Cohen, N., Ennaji, H., Bouchrif, B., Hassar, M.H. 2007.Comparative study of microbiological quality of raw poultry meat at various seasons and for different slaughtering processes in Casablanca (Morocco). Poultry Science Association, 16: 502-508.

Dan, S.D., Mihaiu, M., Rotaru, O., Ioana, D. 2008. Microbiological hazard evaluation represented by the pasychrotrophic grams from the level of a vain carcasses. Buletin USAMV Veterinary Medicine, 65(2): 2008, Pissn.1843-5270; Eissn.1843-5378.

Daoud, J.R. 2012. Microbial quality of frozen chicken meat at grocery stores in Qena city, International Conference and Exhibition on Food Processing \& Technology, 2012.

Davies, A., Board, R. 1998. The microbiology of meat and poultry $1^{\text {st }}$ Ed., Edmundsburg Press, Ltd., Edmunds, London, UK.

Egyptian Organization for Standardization 'E.O.S, 1090' 2005. Egyptian Organization for Standardization and quality control. Egyptian Standards for frozen poultry and rabbit.

Egyptian Organization for Standardization 'E.O.S, 63/9'’2006. Egyptian Organization for Standardization and quality control. Egyptian Standards for poultry meat products treated with heat.

Egyptian Organization for Standardization 'E.O.S, 63/10'”2006. Egyptian Organization for Standardization and quality control. Egyptian Standards for poultry meat products treated with heat.

Egyptian Organization for Standardization 'E.O.S, 63/11', 2006. Egyptian Organization for Standardization and quality control. Egyptian Standards for poultry meat products treated with heat. 
El-Marrakchi, A., Bennour, M., Bouchriti, N., Hamama, A., Tagafait, H. 1990. Sensory, chemical and microbial assessment of Moroccan sardines (Sardina pilch ardus) stored in ice. j. Food Protect., 53:1-5.

Fathy-Eman 2012. Chemical analysis of chicken meat with relation to its quality. Ph.D. Thesis, Fac. Vet. Med. Moshtohor, Benha University.Egypt.

Feng, P., Weagent, S.D., Grant, M.A. 2002. Bacteriological Analytical Manual.Online.www.lib.ncsu.edu/pu bweb.ETDdb/web root/collection/av ailable/etd-04102005213953/unrestricted/etd.pdf.

Fraizer, W. C., Westhoff, D.C. 1984. Food microbiology3rd Ed.4 $4^{\text {th }}$ Repr. Tata McGraw-Hill Publ. Company LTD New-Delhi.

Gill, C.O., McGinnis, K.R., Houde, A.1996. The hygienic condition of manufacturing beef destined for the manufacture of hamburger patties. Food Microbiol, 13:391.

Hassan -Ola 2015. Microbiological status of poultry carcasses from retailed outlets in Alexandria province. M.V.Sc., Thesis, Fac. Vet. Med., Alex. Univ. Egypt.

Hassan, M.A., Shaltout, F. 2004. Comparative study on storage stability of beef, chicken meat and fish at chilling temperature, Alex. J. Vet. Sci., 20-21:30. Egypt.

Hassan-Fatma El-zhraa 2013. Chemical profile of some poultry meats, $\mathrm{Ph}$. D. V. Sc. Thesis, Fac. Vet. Med. Moshtohor, Benha University.Egypt.

Hassanin-Faten, S., Hassan, M.A 2003. Chemical indices of incipient deterioration in chicken cut-up products. Benha-V.M.J., 14(2):54-65. Egypt.

Hathout-Amal, S., Aly-soher, E. 2010. Role of lactic acid bacteria as a biopreservative talbina. J. American Sci.

International Organization of Standardization "ISO" 2003. No. 6887-2 Microbiology of food and animal feeding stuffs - Preparation of test samples, initial suspension and decimal dilutions for microbiological examination -- Part 2: Specific rules for the preparation of meat and meat products.

International Organization for Standardization "ISO" 2004. No.11291-1. Microbiology of food and animal feeding stuffs - Horizontal methods for detection and enumeration of Enterobacteriaceae part 2: colony count. method.

Jaturasitha, S., Kayan, A., Wicke, M. 2008. Carcass and meat characteristics of male chickens between Thai indigenous compared with improved layer breeds and their crossbred. Arch Tierzucht.; 51: 283-294.

Javadi, A., Safarmashaei, S. 2011. Microbial profile of marketed broiler meat. Middle-East J. Sci. Res., 9 (5): 652-656.

Jay, J. M. 1972. Metabolism and detection of microbial spoilage in meat at low temperature- A status report. J. Milk Food Technol., (35):467-470.

Kunz, B.1994. Grundrib der lebensmittelMikrobiologie. 2. Überarbeitete und erweiterte Auflage, Behr's, Hamburg, Germany.

Liu, X.D., Jayasena, D.D., Jung, Y., Jung, S., Kang, B.S., Heo, K.N., Lee, J.H., Jo, C. 2012. Differential proteome analysis of breast and thigh muscles between Korean native chickens and commercial broilers. Asian Australas. J. Anim. Sci.; 25:895-902

Owens, C. M. 2001. Coated poultry products. In poultry meat processing. Ed. Sams, A. R. CRC, Press.

Raharjo, S., Sofos, J. N. 1993. Methodology for measuring malonaldehyde as a product of lipid oxidation in muscle tissues, Meat Science, 35: 145-169.

Reddy, S., Ilenrickson, R.I., Olson, H.C.1970.The influence of lactic acid culryres on ground beef quality Oklahoma Agr i. Experiment Station, 
Stillwater, Oklahoma. J. Food Sci., 35, 787.

Roberts, D. 1990. Sources of food infection lancet-British-edition.336: 8719 8859.

Saikia, P., Joshi, S.R. 2010. Retail market poultry meats of North-East India, A microbiological survey for pathogenic contaminant. Res. J. Microbiol., 5(1):36-43.

Salem-Amany, M.1992. Biological analytical studies on incipient deterioration of beef meat and liver. M. V. Sc, Meat hygiene, Fac. Vet. Med., Moshtohor, Zagazig Univ., Benha Branch.Egypt.

Santosh Kumar, H.T., Paul, U.K., Mandel, P.K., Das, C.D. 2014. Changes in the quality of dressed chicken obtained from different sources during frozen storage, Explor. Anim. Med. Res, 4, (1): 96-97.

Shams El-Din, M.H.A., Ibrahim, H.M. 1990. Cooking effects on fat and fatty acids composition of chicken muscles, Die Nahurung,34(3):207212.

Trout, Osburn 1997. Meat from dairy cows: possible microbiological hazards and risks. Rev. Sci. Technol. 16(2):405414.

United States Department of Agriculture "USDA"2012. Accessed February 8, 2013. Livestock and Poultry. World Markets and Trade. 2012 http://www.fas.usda.gov/psdonline/ci rculars/livestock_poultry.pdf

Yadav, M. M., Tale, S., Sharda, R., Sharma, V., Tiwari, S., Garg, U. K. 2006. Bacteriological quality of sheep meat in Mhow town of India. Inter.J.Food Science. Technol., 41: 1234- 1238.

Yassien-Nessrein, M.2003. Effect of storage condition on the quality parameters of differently treated fish. Ph.D. Thesis, Fac. Of Agri, Ain Shams. Egypt. 